\title{
Thyroid Gland Signet Ring Cell Follicular Adenoma
}

National Cancer Institute

\section{Source}

National Cancer Institute. Thyroid Gland Signet Ring Cell Follicular Adenoma. NCI

Thesaurus. Code C46115.

A thyroid gland adenoma characterized by the presence of signet ring cells that stain positive for thyrog lobulin. 